\title{
ПРІОРИТЕТНИЙ ВИБІР СТУДЕНТІВ ВИЩИХ НАВЧАЛЬНИХ ЗАКЛАДІВ РІЗНИХ РЕГІОНІВ УКРАЇНИ ЩОДО ВИДІВ РУХОВОЇ АКТИВНОСТІ (ВИДІВ СПОРТУ)
}

Глоба Т. А. Пріоритетний вибір студентів вищих навчальних закладів різних регіонів України щодо видів рухової активності (видів спорту).

Розглянуто пріоритетний вибір студентів вищих навчальних закладів різних регіонів України щодо видів рухової активності (видів спорту). У дослідженні використано результати анкетного опитування 290 студентів вищих навчальних закладів різних регіонів України. Наведено аналіз публікацій науковців різних країн щодо вибору видів рухової активності студентів. На основі аналізу літературних джерел та проведеного анкетування 3'ясовано ставлення студентів до пріоритетного вибору щодо видів рухової активності (видів спорту). Доведено актуальність і доцільність обраної проблеми дослідження.

Ключові слова: фізичне виховання, рухова активність, студент, заняття, настільний теніс.

Глоба Т. А. Приоритетный выбор студентов высших учебных заведений различных регионов Украины по видам двигательной активности (видов спорта).

Рассмотрен приоритетный выбор студентов высших учебных заведений различных регионов Украины по видам двигательной активности (видов спорта). В исследовании использованы результаты анкетного опроса 290 студентов высших учебных заведений различных регионов Украины. Приведен анализ публикаций ученых разных стран по выбору видов двигательной активности студентов. На основе анализа литературных источников и проведенного анкетирования выяснено отношение студентов к приоритетному выбору по видам двигательной активности (видов спорта). Доказана актуальность и целесообразность выбранной проблемы исследования.

Ключевые слова: физическое воспитание, двигательная активность, студент, занятия, настольный теннис.

Hloba T. A. The prime choice of students of higher educational establishments from various regions of Ukraine concerning the types of physical activity (sports).

The prime choice of students of higher educational establishments from various regions of Ukraine concerning the types of physical activity (sports) is considered. The results of the questionnaire survey of 290 university students from various regions of Ukraine are used in the research. The publications of scientists from different countries are analyzed concerning different types of students' physical activity. Based on analysis of the literature and the conducted survey the ratio of students' preference for types of physical activity (sports) is clarified. The urgency of the problem as well as its viability has been proved.

Key words: physical education, physical activity, student, training, table tennis.

Задля реалізації наказу Міністерства освіти і науки від 26 січня 2015 року № 47 «Про 
особливості формування навчальних планів на 2015-2016 навчальний рік» та норм Закону України «Про вищу освіту», для використання в роботі, надаються роз'яснення та рекомендації вищим навчальним закладам, що заняття з фізичної культури в спортивних секціях можуть бути організовані як факультативи (тобто за бажанням студентів).

На сучасному етапі розвитку суспільства одним із пріоритетних напрямків у галузі освіти $є$ створення максимально сприятливих умов для всебічного гармонійного розвитку студентської молоді з урахуванням іiі індивідуальних морфофункціональних, фізичних, соматичних, психічних особливостей.

Фізичне виховання як невід'ємний складник освіти забезпечує можливість набуття кожною людиною необхідних науково обгрунтованих знань про здоров'я і засоби його зміцнення, про шляхи i методи протидії хворобам, методики досягнення високої працездатності та тривалої творчої активності.

Світовий досвід свідчить, що рухова активність людини впродовж усього життя запобігає захворюванням та поліпшує стан здоров'я. Достатній рівень рухової активності студентів $€$ основою належного розвитку організму (Є. Котов, О. Куц, В. Романенко, С. Савчук та інші).

Науковці В. Афанасьєв, Ю. Мартинов, В. Шишацька, В. Щербаченко, вказують на те, що рухова діяльність є категорією мобільною й індивідуальною впродовж молодого віку, що зумовлено біологічними й суспільними показниками, що великі фізичні навантаження не гарантують зміцнення стану здоров'я, а умови фізичної підготовки студентів повинні бути спрямовані на рівень масової рухової діяльності [2, с. 4].

Руховий компонент, на думку науковців В. Афанасьєва, Ю. Мартинова, В. Шишацької, В. Щербаченко, є основним у процесі формування способу життя, проте невеликий відсоток студентської молоді зазвичай займається фізичними вправами й видами спорту. Автори зазначають необхідність упроваджувати нові форми занять фізичною культурою та враховувати забезпечення інтересів студенів, умов навчання, стан здоров'я, стать та вік студентів [2, с. 4].

У процесі навчальної діяльності на системи організму студентів діє значна кількість негативних чинників, які викликають відхилення у стані здоров'я. Науковці Д. Бойко, Е. Церковна та інші, зазначають, що серед них: низька рухова активність, нервово-емоційне напруження, розумові перевантаження і стреси, особливо в період сесій, тривалість навчального дня, порушення режиму харчування, наявність шкідливих звичок [9, с. 130; 4, c. 22].

Пріоритетним напрямком у підвищенні мотивації студентів до занять фізичною культурою і спортом, за визначенням Л. Лубишевої, має стати відмова від стандартизації навчальних програм ВНЗ нефізкультурного профілю і створення більшої кількості альтернативних програм відповідно до кожного виду фізичної культури з урахуванням регіональних, національних, культурно-історичних традицій, матеріально-технічного оснащення спортивних комплексів кожного конкретного ВН3 [10, с. 11].

На думку С. Сичова, розвиток і здоров'я студентської молоді залежить від того, наскільки успішно викладачу вдається перебудувати навчально-виховний процес i спрямувати його на активну позицію до занять фізичною культурою, творче перетворення рухової активності, самоуправління й саморегуляцію поведінки студента [8, с. 115].

Mema cmammi - проаналізувати пріоритетний вибір студентів вищих навчальних закладів різних регіонів України щодо видів рухової активності (видів спорту). Методи дослідження: теоретичний аналіз, контент-аналіз психолого-педагогічної літератури й

Педагогіка вищої та середної школи. - 2015. - Вип. 45 
літератури з фізичної культури та спорту; анкетування студентів.

Завдання дослідження: 1. Здійснити аналіз психолого-педагогічної літератури та літератури з фізичної культури і спорту, інформації з мережі Інтернет щодо вибору видів рухової активності (видів спорту) студентів вищих навчальних закладів різних регіонів України. 2. Провести анкетування щодо пріоритетного вибору студентів вищих навчальних закладів різних регіонів України видів рухової активності (видів спорту).

Чинна нині організація фізичного виховання у вищих навчальних закладах України недостатньо ефективна для підвищення рівня фізичної підготовленості, здоров'я, професійно важливих психофізіологічних якостей та залучення значної кількості студентів до систематичних занять.

Нині актуальною є низка проблем в організації фізичного виховання у вищих навчальних закладах України. Науковці О. Попрошаев, В. Мунтян, стверджують, що необхідно приділити увагу оптимізації фізичного виховання студентів, зокрема організації занять за вільним вибором різних видів спорту, рухової активності й оздоровчої спрямованості. На думку авторів, побудова навчальних занять на основі обраного виду фізкультурної діяльності вимагає значних організаційних заходів, формування спеціальних навчальних програм, відповідної до матеріальної бази та висококваліфікованих кадрів [7, c. 67].

Чинна програма 3 курсу фізичного виховання не цікава для сучасного покоління студентської молоді. Традиційна форма занять з фізичного виховання сприяє зниженню зацікавленості студентів процесом фізичного виховання, на думку О. Малімона, та призводить до формального відбування навчальних занять 3 цього предмета [6, с. 19].

Питання вдосконалення робочих програм 3 предмета «Фізична культура» студентів основного відділення, на думку Л. Андрющенко, вивчені недостатньо, спортивноорієнтована технологія навчання у навчальному процесі з фізичного виховання студентів основного відділення не знаходять належного відображення в науково-методичній літературі [1].

Науковці Г. Коник, В. Темченко, Т. Усова зазначають, що форма організації занять 3 фізичного виховання в групах із пріоритетним використанням того чи іншого виду спорту $є$ для студентів більш прийнятною порівняно 3 традиційним підходом до проведення занять [5].

Такої ж думки дійшли також науковці Н. Бондарчук, Г. Власов, які вважають, що саме спортивно-орієнтована форма організації фізичного виховання, що передбачає заняття улюбленим видом спорту, сприяє зміцненню здоров'я студентів, підвищенню рівня фізичної підготовленості, розвитку позитивної мотивації до занять фізичними вправами та спортом [3, c. 157].

Для покращення оптимізації навчального процесу 3 фізичного виховання для студентів вищих навчальних закладів необхідно враховувати кілька чинників: популярність виду спорту серед студентів, наявність фахівців з видів спорту які входять до викладацького складу кафедри фізичного виховання, відсутність гарної оснащеності кафедр ВНЗ необхідним обладнанням, залами, роздягальнями та душовими, тренажерами та інвентарем, що у свою чергу негативно позначається на спробах створення викладачами професійного викладання свого предмета.

Для розв'язання поставлених завдань нами було проведено анкетне опитування серед студентської молоді різних вищих навчальних закладів України. В анкетуванні взяли участь студенти 1-х, 2-х та 3-х курсів, загальна кількість студентів, яка брала участь в анкетуванні, 
склала 290 чоловік, віком від 17 до 19 років. 3 метою з'ясування щодо пріоритетного вибору студентів вищих навчальних закладів різних регіонів України видів рухової активності (видів спорту) нами було проведено дослідження студентів за спеціально розробленою анкетою. У дослідженні взяло участь 60 студентів Дніпропетровського національного університету імені Олеся Гончара (ДНУ ім. О. Гончара), 46 студентів Придніпровської академії будівництва та архітектури (ПДАБА), 66 студентів Івано-Франківського національного технічного університету нафти і газу (ІФНТУНГ), 60 студентів Академії митної служби України м. Дніпропетровськ (АМСУ), 58 студентів Дніпропетровського національного університету залізничного транспорту імені Всеволода Лазаряна (ДНУЗТ ім. В. Лазаряна).

Отримані результати відповідей студентів на запитання анкети «Яким видом спорту із поданого переліку Ви хотіли б займатися?» дозволив 3'ясувати, що із 290 студентів різних вищих навчальних закладів України легкою атлетикою хотіли б займатись - 9,66\% студентів, баскетболом - 21,03\%, настільному тенісу надали перевагу - 36,21\% опитаних, волейболу $22,1 \%$, футболом зацікавилось - 26,21\% респондентів, бадмінтоном - 21,72\%, гімнастикою $18.23 \%$ респондентів, плаванням хотіли б займатись - 20,69\%, іншими видами спорту (важка атлетика, шахи) - 4,14\% опитаних (студенти обирали кілька видів спорту) (табл. 1).

Таблиия 1

\section{Розподіл відповідей студентів, опитаних щодо вибору видів спорту в різних} вищих навчальних закладах України

\begin{tabular}{|c|c|c|c|c|}
\hline Вид спорту & $\begin{array}{c}\text { Кількість } \\
\text { відповідей } \\
\text { дівчат }\end{array}$ & $\begin{array}{c}\text { Кількість } \\
\text { відповідей } \\
\text { хлопців }\end{array}$ & $\begin{array}{c}\text { Загальна } \\
\text { кількість } \\
\text { відповідей }\end{array}$ & $\begin{array}{c}\text { Загальна } \\
\text { кількість (\%) }\end{array}$ \\
\hline Легка атлетика & 11 & 17 & 28 & 9,66 \\
\hline Баскетбол & 24 & 37 & 61 & 21,03 \\
\hline Настільний теніс & 56 & 49 & 105 & 36,21 \\
\hline Волейбол & 35 & 29 & 64 & 22,1 \\
\hline Футбол & 17 & 59 & 76 & 26,21 \\
\hline Бадмінтон & 47 & 16 & 63 & 18,23 \\
\hline Гімнастика & 42 & 11 & 53 & 20,69 \\
\hline Плавання & 29 & 31 & 60 & 4,14 \\
\hline $\begin{array}{c}\text { Інше (важка } \\
\text { атлетика, шахи) }\end{array}$ & 1 & 11 & 12 & \\
\hline
\end{tabular}

Слід зазначити, що найбільша кількість респондентів - 36,21\% надали перевагу такому виду спорту, як настільний теніс, відповідно - 56 дівчат та 49 хлопців із різних вищих навчальних закладів України. Найменший відсоток 9,66\%, а саме (11 дівчат та 17 хлопців) хотіли б займатись на заняттях 3 фізичного виховання легкою атлетикою. На питання «Вкажіть інше», студенти зазначили такі види спорту, як важка атлетика та шахи $(4,14 \%)$.

Відповіді студентів різних вищих навчальних закладів України (ДНУ ім. О. Гончара, ПДАБА, ІФНТУНГ, АМСУ, ДНУЗТ ім. В. Лазаряна) щодо питання «Яким видом спорту із поданого переліку Ви хотіли б займатися?» розподілилися так (табл. 2).

Таблиия 2

Розподіл відповідей студентів щодо вибору видів спорту в різних вищих навчальних закладах України (\%)

\begin{tabular}{|c|c|c|c|c|c|}
\hline Вид спорту & $\begin{array}{c}\text { ДНУ } \\
\text { імені } \\
\text { О. Гончара }\end{array}$ & ПДАБА & ІФНТУНГ & АМСУ & $\begin{array}{c}\text { ДНУЗТ } \\
\text { імені } \\
\text { В. Лазаряна }\end{array}$ \\
\hline Легка атлетика & 10 & 4,35 & 6,06 & 16,67 & 10,34 \\
\hline
\end{tabular}




\begin{tabular}{|c|c|c|c|c|c|}
\hline Вид спорту & $\begin{array}{c}\text { ДНУ } \\
\text { імені } \\
\text { О. Гончара }\end{array}$ & ПДАБА & ІФНТУНГ & АМСУ & $\begin{array}{c}\text { ДНУЗТ } \\
\text { імені } \\
\text { В. Лазаряна }\end{array}$ \\
\hline Баскетбол & 31,67 & 19,56 & 16.67 & 20,0 & 17,24 \\
\hline Настільний теніс & 46,67 & 34,78 & 33,33 & 30,0 & 36,21 \\
\hline Волейбол & 20,0 & 8,7 & 18,18 & 26,67 & 34,48 \\
\hline Футбол & 35,0 & 26.1 & 28,79 & 20.0 & 25,86 \\
\hline Бадмінтон & 23,33 & 15,22 & 27,27 & 13,33 & 27,59 \\
\hline Гімнастика & 26,67 & 17,39 & 15,15 & 18.33 & 13,79 \\
\hline Плавання & 13,33 & 13,04 & 15,15 & 30,0 & 31,03 \\
\hline Інше (важка атлетика, шахи) & - & 4,35 & 3,03 & 6,67 & 6,9 \\
\hline
\end{tabular}

Результати анкетування показують, що студенти бажають займатись різноманітними видами спорту. Більшість респондентів надають перевагу одразу кільком видам спорту. Найбільш популярними серед студентської молоді різних вищих навчальних закладів України є ігрові види спорту, а саме - баскетбол, настільний теніс, волейбол, футбол, бадмінтон. Настільному тенісу надали перевагу від 30,0 \% до 46,67 \% опитаних, що в свою чергу становив найбільший відсоток серед відповідей студентів.

Вивчаючи інтереси студентів до різних видів спорту, завданням було з'ясувати якому виду спорту з циклу «спортивні ігри» респонденти надають перевагу. Так із 290 студентів різних вищих навчальних закладів України футбол зацікавив - 16,55 \% опитаних, волейболу надали перевагу - 17,59 \% респондентів, настільному тенісу - 31,38 \% опитаних, баскетболу - 15,2 \%, бадмінтон обрали - 18,96 \% студентів (рис. 1).

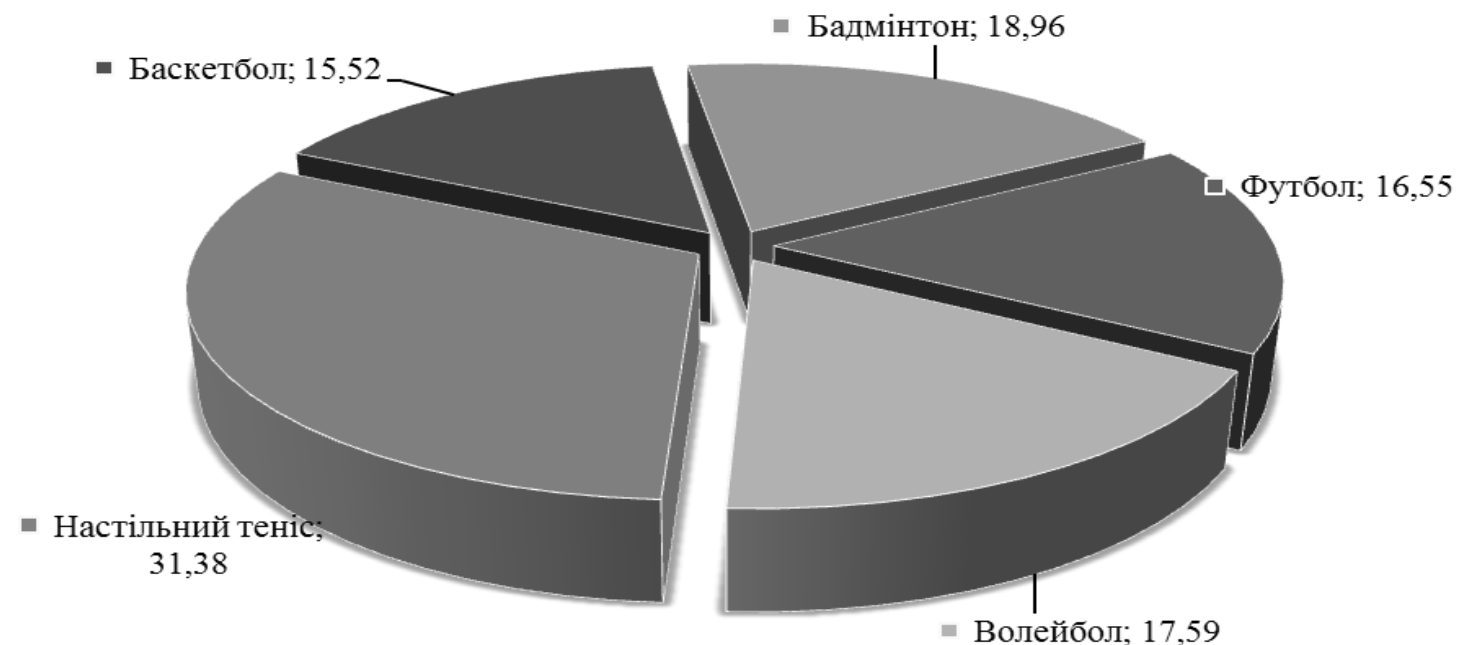

Рис. 1. Результати відповідей студентів щодо інтересу до ігрових видів спорту (\%)

Аналіз результатів анкетного опитування щодо інтересу до ігрових видів спорту у студентів розподілився так: футболу надали перевагу 23,33\% респондентів (ДНУ ім. О. Гончара), - 15,22 \% (ПДАБА), - 15,15\% (ІФНТУНГ), - 13,33\% (АМСУ), - 15,25\% (ДНУЗТ ім. В. Лазаряна). Волейболу - 10,0 \% респондентів (ДНУ ім. О. Гончара), - 19,57 \% (ПДАБА), - 12,12\% (ІФНТУНГ), - 25,0 \% (АМСУ), - 22,41 \% (ДНУЗТ ім. В. Лазаряна). Настільному тенісу надали перевагу - 40,0\% опитаних (ДНУ ім. О. Гончара), - 34,78 \% (ПДАБА $),-28,79 \%$ (ІФНТУНГ), - 30,0 \% (АМСУ), - 24,14\% (ДНУЗТ ім. В. Лазаряна). Баскетбол обрали - 16,67 \% студентів (ДНУ ім. О. Гончара), - 6,52 \% (ПДАБА), - 21,21 \% (ІФНТУНГ), - 16,67 \% (АМСУ), - 13,79 \% (ДНУЗТ ім. В. Лазаряна). Бадмінтон зацікавив - 
10,0 \% респондентів (ДНУ ім. О. Гончара), - 23,91 \% (ПДАБА), - 22,73\% (ІФНТУНГ), 15,0 \% (АМСУ), - 24,14 \% (ДНУЗТ ім. В. Лазаряна) (рис. 2).

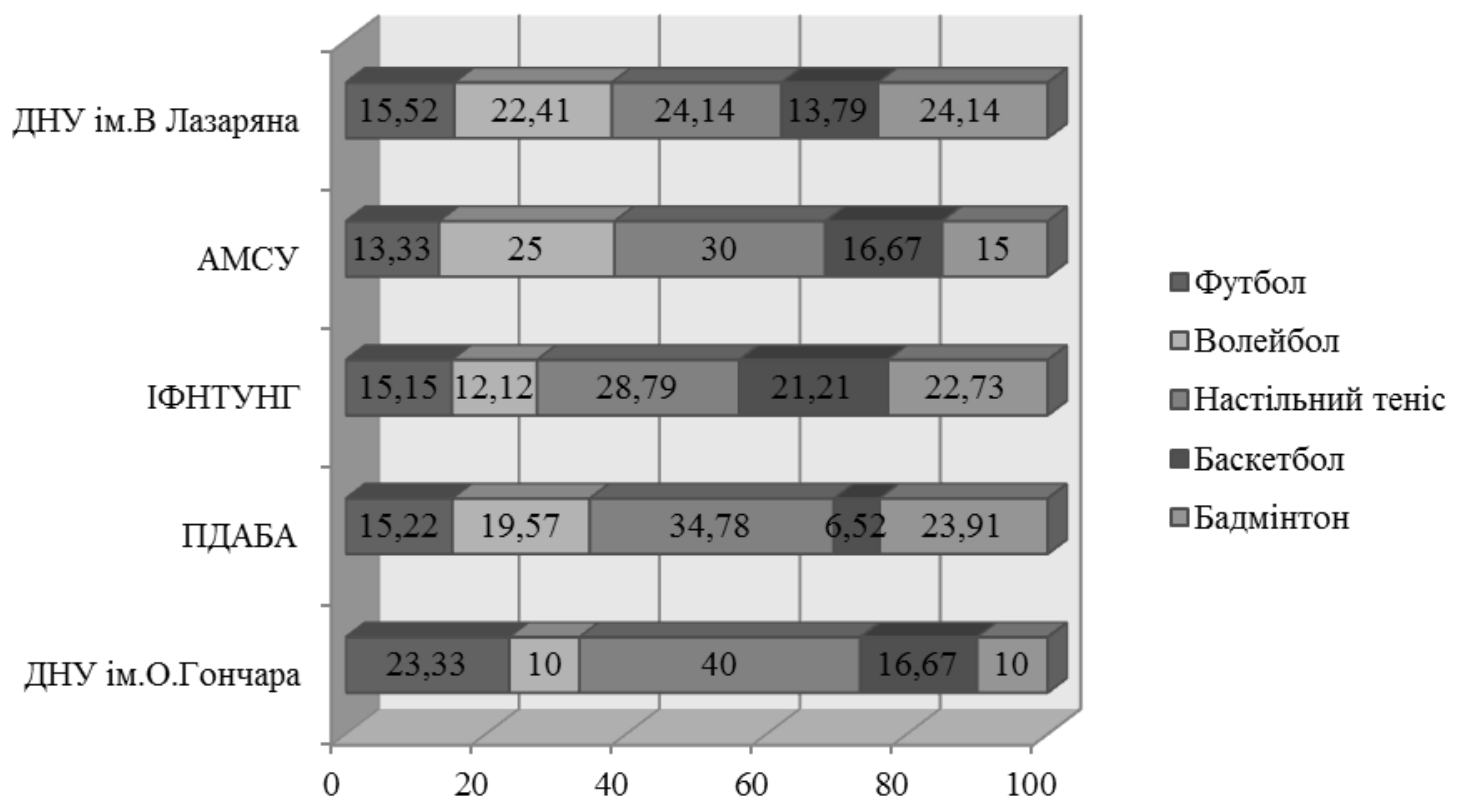

Рис. 2. Результати відповідей студентів щодо інтересу до ігрових видів спорту різних вищих навчальних закладів України (\%)

Аналіз результатів анкетного опитування засвідчив таке: на питання: «Якому виду спорту 3 циклу «спортивні ігри» студенти надають перевагу» показав, що найбільшу кількість відповідей надали студенти Дніпропетровського національного університету імені Олеся Гончара, такому виду спортивних ігор, а саме - настільному тенісу (40,0\%). Також настільному тенісу надали перевагу - 34,78\% респондентів Придніпровської академії будівництва та архітектури, та хотіли б займатись - 30,0 \% студентів Академії митної служби України. Менш популярним видом спорту серед вищих навчальних закладів України виявився баскетбол $(15,2 \%)$, найменший відсоток- $6,52 \%$ склав у студентів Придніпровської академії будівництва та архітектури.

Аналіз психолого-педагогічної літератури, літератури з фізичної культури та спорту та результати анкетування студентів вищих навчальних закладів України щодо вибору видів спорту показав, що необхідно змінювати підходи до викладання дисципліни «фізичне виховання». Необхідно надати сучасному студенту більш широкий вибір тих видів спорту, які йому подобаються, чим здійснити мотивацію та залучити до занять фізичним вихованням.

Подальші дослідження передбачається провести в напрямку вивчення такого виду спорту, як настільний теніс, як перспективного виду спорту серед студентської молоді у вищих навчальних закладах України.

\section{Література}

1. Андрющенко Л. Б. Спортивно ориентированная технология обучения студентов по предмету «Физическая культура» / Л. Б. Андрющенко // Теория и практика физ. культуры. 2002. - № 2. - С. 47-54. 2. Афанасьєв В. В. Педагогіка, психологія та медико-біологічні проблеми фізичного виховання і спорту: [наукова монографія]/ за редакцією проф. Єрмакова С.С. «Гіпокінезія студентів вищих учбових закладів»/ В. В. Афанасьєв, Ю. О. Мартинов, В. І. Шишацька, В.К. Щербаченко. - Харків : ХДАДМ (ХХПІ), 2009. - 
№ 1. - 160 с. 3. Бондарчук Н. Я. Належні норми рухових можливостей студентів Ужгородського національного університету / Н. Бондарчук, В. Чернов, Л. Ляховець // Спортивний вісник Придніпров’я: [науково-практичний журнал]. - 2010. - № 2. - С. 157159. 4. Бойко Д. В. Сучасний стан та перспективні напрямки вдосконалення фізичного виховання студентів ВНЗ України III-IV рівнів акредитації / Д. В. Бойко // Педагогіка, психологія та медико-біологічні проблеми фізичного виховання і спорту. - Харків : ХДАДМ (ХХПІ), 2012. - № 1. - С. 22-25. 5. Коник Г. А. Современные тенденции организации физического воспитания студентов / Г. А. Коник, В. А. Темченко, Т. Е. Усова // Физическое воспитание студентов творческих специальностей. - 2009. - № 4. - С. 68-74. 6. Малімон О. О. Диференційований підхід у процесі фізичного виховання студентів: автореф. дис. на здобуття наук. ступеня канд. наук з фіз. виховання і спорту: спец. 24.00.02 / О. О. Малімон. - Луцьк, 1999. - 19 с. 7. Попрошаев А. В. Приемущества секционной формы организации учебного процесса по дисциплине «Физическое воспитание» / А. В. Попрошаев, В. С. Мунтян // Физическое воспитание студентов: [научный журнал]. - Харьков, ХОВНОКУ-ХДАДМ, 2011. - № 4. - С. 67-71. 8. Сичов С. О. Прилучення студентської молоді до цінностей фізичної культури в процесі атлетичного тренування / С. О. Сичов //Педагогіка, психологія та медико-біологічні проблеми фізичного виховання і спорту. - Харків : ХДАДМ (ХХПІ), 2011. - №1. - С. 115-118. 9. Церковная Е. В. Биологический возраст и темпы старения студентов с разным уровнем двигательной активности / Е. В. Церковная, А. Л. Нефедова, В.Н.Осипов, О. А. Миргород // Физическое воспитание студентов: [научный журнал]. - Харьков, ХОВНОКУ-ХДАДМ, 2011. - № 1. C. 130-133. 10. Lubysheva L. I. The concept of sports training: methodology development and technology implementation // Physical culture: education, education and training. - 1996. - № 1. P. 11-17.

УДК $378+613$

Наталія Гуменко, Тарас Андріанов, Валентина Марчик

\section{РУХОВА АКТИВНІСТЬ І ПРАВИЛЬНЕ ХАРЧУВАННЯ У ФОРМУВАННІ ЗДОРОВОГО СПОСОБУ ЖИТТЯ СТУДЕНТСЬКОЇ МОЛОДІ}

Гуменко Н. Ф., Андріанов Т. В., Марчик В. I. Рухова активність і правильне харчування у формуванні здорового способу життя студентської молоді.

Пріоритетність фізичного виховання у процесі виховання дітей, закріплення здорового способу життя в молоді та його підтримання у зрілому віці повинно бути важливою державною політикою. Рухова активність та правильне харчування є запорукою гармонійного фізичного розвитку, нормалізації ваги, наявності енергії й почуття здоров'я. Використання електронних ресурсів сприяє підвищенню усвідомленості й зацікавленості студентів у питаннях формування навичок здорового способу життя i, як наслідок, рівня фізичної підготовленості.

Ключові слова: здоровий спосіб життя, рухова активність, правильне харчування, студент, електронний ресурс.

Гуменко Н. Ф., Андрианов Т. В., Марчик В. И. Двигательная активность и правильное питание в формировании здорового образа жизни студенческой молодежи.

Приоритетность физического воспитания в процессе воспитания детей, закрепление 